\title{
Identifikasi Karakteristik Kimiawi dan Daya Simpan Kefir Susu Jagung (Zea mays L. Saccharata)
}

\author{
Yanesti Nuravianda Lestari ${ }^{1}$, Nur Amin ${ }^{2 *}$, Duyung Ananda ${ }^{3}$, Nimas Ayu Rengganis ${ }^{4}$ \\ ${ }^{1}$ Program Studi Gizi S1, Jurusan Ilmu Kesehatan Masyarakat, Fakultas Ilmu Keolahragaan, \\ Universitas Negeri Semarang, Semarang \\ ${ }^{2}$ Program Studi Ilmu Keolahragaan, Fakultas Kesehatan, Universitas Ngudi Waluyo, \\ Ungaran \\ ${ }^{3,4}$ Program Studi Gizi, Fakultas Ilmu Kesehatan, Universitas Nahdlatul Ulama Surabaya, \\ Surabaya \\ email*: nuramin@unw.ac.id
}

\section{ABSTRACT}

Kefir is a food-based on pasteurized milk fermented using lactic acid bacteria, acetic acid bacteria, and yeast. The study aims to analyze proximate levels (carbohydrates, proteins, and fats) and identify the characteristics of sensory changes during storage.

This true experimental study uses a complete randomized design with 1 factor. The composition of corn milk kefir consists of 3 levels (K1=corn milk: skimmed milk 100:0; K2=corn milk: skimmed milk 75:25; K3=corn milk: skimmed milk 50:50). Data analysis using One Way Anova showed that carbohydrate content $(10.31 \pm 1,426)$, fat $(0.18 \pm 0.018)$, and protein $(1.83 \pm 0.973)$ significantly different $(p=0.0001)$.

The 35 days of storage in the refrigerator $\left(2-8^{\circ} C\right)$ results in a change in kefir color becoming more faded. The kefir texture before storage is different for each kefir composition and becomes more viscous at the end of the storage period. The sour aroma of kefir will increase during kefir storage. It can be concluded that protein and fat levels increase along with an increase in the amount of skimmed milk addition, while carbohydrate levels decrease at the addition of the most skimmed milk (K3).

Keywords: kefir, proximate, sensory characteristics, shelf-life, skimmed milk

Submitted : 2020-12-15 Accepted:2021-06-29 Published :2021-11-08

\section{PENDAHULUAN}

Kefir merupakan pangan berbahan dasar susu pasteurisasi yang difermentasi menggunakan bakteri asam laktat (BAL), bakteri asam laktat dan khamir. Hasil penelitian Nurliyani dkk (2014) tentang manfaat kefir susu kambing dan susu kedelai menunjukkan bahwa konsumsi kefir dapat menurunkan kadar malondialdehida (MDA) tikus yang diinduksi Diabetes Mellitus. Selain itu, penelitian yang dilakukan subyek pada manusia menunjukkan bahwa suplementasi kefir dapat menurunkan kadar glukosa darah puasa, post prandial dan $\mathrm{HbA}_{1} \mathrm{C}$ serta meningkatkan kadar serum C-peptide (Andrade et al, 2016). Bahan yang seringkali digunakan sebagai bahan baku dalam memproduksi kefir adalah susu segar (whole milk) baik susu sapi maupun susu kambing. Adapun susu skim, meskipun bukan merupakan susu 
segar, namun dapat digunakan sebagai bahan dasar produksi kefir. Kefir yang diproduksi dari susu skim memiliki kandungan lemak lebih rendah dibandingkan dengan kefir yang diproduksi dari susu segar (Safitri dan Swarastuti, 2013). Proses pembuatan kefir dimulai dengan proses pasteurisasi susu pada suhu $85-90^{\circ} \mathrm{C}$ selama 30 menit, kemudian didinginkan hingga mencapai suhu kamar $\left( \pm 28^{0} \mathrm{C}\right)$. susu yang telah dipasteurisasi kemudian ditambahkan dengan kefir grains sebanyak 7\% (w/v) dan diinkubasi selama 24 jam pada suhu $24^{0} \mathrm{C}$ agar berlangsus proses fermentasi (Purnomo dan Muslimin, 2012). Jagung merupakan sumber karbohidrat dan protein yang seringkali dikonsumsi sebagai menu makanan masyarakat Indonesia. Jagung memiliki kandungan pati yang sangat tinggi (72-73\%) yaitu pati amilosa dan amilopektin dengan perbandingan 25-30\% : 70-75\%. Adapun kandungan protein jagung cukup tinggi, yaitu berkisar antara 8-11\%. Jagung juga mengandung asam lemka tidak jenuh, yaitu omega 9 (asam oleat) dan omega 6 (asam lemak linoleat). Kandungan vitamin dan mineral yang terkandung pada jagung antara lain vitamin $\mathrm{A}, \mathrm{K}, \mathrm{Na}, \mathrm{P}, \mathrm{Ca}$ dan $\mathrm{Fe}$ (Suarni dan Widowati, 2015). Oleh karena itu, peneliti tertarik untuk mengkaji tentang perubahan karakteristik kimiawi kefir (karbohidrat, protein dan lemak), warna, tektur, aroma serta daya simpan kefir susu jagung.

\section{METODE PENELITIAN}

Penelitian ini dilaksanakan dengan menggunakan metode true experiment dengan desain penelitian Rancangan Acak Lengkap (RAL) dengan 1 faktor yaitu komposisi kefir susu jagung terdiri dari 3 level:

1. K1 : perbandingan komposisi susu jagung : susu skim 100:0

2. K2 : perbandingan komposisi susu jagung : susu skim 75:25

3. K3 : perbandingan komposisi susu jagung : susu skim 50:50

Tabel 1. Total Perlakuan

\begin{tabular}{clll}
\hline \multirow{2}{*}{ Komposisi kefir } & \multicolumn{3}{c}{ Ulangan ke- } \\
\cline { 2 - 4 } & 1 & 2 & 3 \\
\hline K1 & $\mathrm{K}_{11}$ & $\mathrm{~K}_{12}$ & $\mathrm{~K}_{13}$ \\
K2 & $\mathrm{K}_{21}$ & $\mathrm{~K}_{22}$ & $\mathrm{~K}_{23}$ \\
K3 & $\mathrm{K}_{31}$ & $\mathrm{~K}_{32}$ & $\mathrm{~K}_{33}$ \\
\hline
\end{tabular}

Masing-masing perlakuan dilakukan 3 kali replikasi, sehingga secara keseluruhan terdapat total 9 perlakuan. Total perlakuan desain penelitian Rancangan Acak Lengkap (RAL) disajikan pada tabel 1.

Proses pembuatan kefir dimulai dengan proses pembuatan susu jagung. Jagung manis yang akan digunakan sebagai bahan dasar susu jagung dicuci hingga bersih dan dipipil. Jagung manis pipil kemudian ditambahkan air dengan perbandingan jagung manis: air 1:6 dan diblender \pm 10 menit hingga halus. Pasta 
jagung yang telah terbentuk kemudian disaring dan ampas jagung disisihkan. Sebelum dimasak, terlebih dahulu ditambahkan susu skim (sesuai komposisi) dan gula pasir sebanyak $8 \%(w / v)$. Susu jagung mentah kemudian dipasteurisasi pada suhu $85-90^{\circ} \mathrm{C}$ selama 30 menit, Kemudian didinginkan hingga mencapai suhu kamar $\left( \pm 28^{\circ} \mathrm{C}\right)$. Susu jagung yang telah dipasteurisasi kemudian ditambahkan dengan kefir grains sebanyak 7\% (w/v) dan diinkubasi selama 24 jam pada suhu $24^{\circ} \mathrm{C}$ agar berlangsung proses fermentasi (Purnomo dan Muslimin, 2012). Pada saat susu sudah menggumpal, susu kemudian disaring menggunakan saringan plastik. Proses ini untuk memisahkan antara kefir hasil fermentasi dan kefir grains. Kefir kemudian dimatangkan (aging) selama 1-3 hari pada suhu $5-10^{\circ} \mathrm{C}$. Sebelum kefir digunakan untuk analisis dan perlakuan, kefir disimpan di dalam refrigerator (Balai Besar Penelitian dan Pengembangan Pascapanen Pertanian, 2007).

Analisis proksimat kefir terdiri dari analisis kadar protein, kadar lemak, dan kadar karbohidrat. Adapun pengukuran kadar protein menggunakan metode Kjeldahl (960.52 AOAC 1998), pengukuran kadar lemak menggunakan metode Weibull (SNI 01-2891-1992) pengukuran kadar karbohidrat menggunakan metode Luff Scrhrool (SNI 01-2891- 1992). Uji daya simpan Jurnal Gizi 10 (2) 2021 dilakukan dengan mengamati perubahan sensorik yang terjadi selama penyimpanan kefir dalam suhu refrigerator $\left(2-8^{0} \mathrm{C}\right)$. Waktu pengamatan berlangsung selama 35 hari, dilakukan di awal dan di akhir penelitian. Adapun perubahan sensorik yang diamati adalah warna, aroma, dan tekstur kefir di awal dan di akhir penelitian.

Unit eksperimental yang digunakan dalam penelitian ini terdiri dari bahanbahan utama sebagai berikut:

\section{Bibit Kefir (Kefir Grains)}

Bibit kefir diperoleh dari Rumah Kefir Juanda Surabaya yang beralamat di JL. Mandala IV / 451 Ds. Semambung Gedangan - Juanda - Surabaya. Bibit kefir berwarna putih kekuningan, berbentuk butiran gumpalan yang berukuran antara 1$15 \mathrm{~mm}$.

\section{Jagung Manis}

Jagung manis yang digunakan sebagai bahan baku pembuatan susu jagung diperoleh dari pasar lokal. Adapun kriteria jagung manis yang digunakan sebagai unit eksperimen dalam penelitian ini harus segar, berdaun lembab berwarna hijau muda, memiliki serabut berwarna cokelat tua dan masih melekat di bagian jagung, jagung terbungkus pada tongkolnya, memiliki biji penuh dalam satu bonggolnya, biji jagung masih segar dan tidak keriput.

\section{Susu Skim}

Susu skim yang digunakan dalam 
penelitian ini adalah susu skim dalam bentuk bubuk yang dibeli dari CV. Nura Jaya yang berlokasi di Semampir Selatan II No.2, Medokan Semampir, Sukolilo, Surabaya.

\section{Gula Pasir}

Gula pasir yang digunakan dalam penelitian ini dibeli di pasar tradisional. Gula pasir yang akan digunakan sebagai unit eksperimen dalam penelitian ini harus berwarna putih kekuningan, tidak terdapat kotoran dan tidak menggumpal.

Data yang telah terkumpul kemudian akan dilakukan proses edit data sebagai tahap pertama pengolahan data. Pada tahap ini data hasil penentuan daya simpan dikoreksi ulang. Tahap selanjutnya adalah melakukan coding terhadap data yang telah diedit, yaitu dengan mengkonversi dan mengkategorikan data. Adapun tahap selanjutnya adalah melakukan tabulasi data yaitu menyajikan data yang telah diolah ke dalam bentuk tabel distribusi frekuensi. Seluruh data yang terkumpul dianalisis menggunakan software SPSS 16 for Windows. Data karakteristik kimiawi dan daya simpan dianalisis secara kualitatif dan kuantitatif dengan analisis deskriptif yaitu menyajikan data hasil analisis dengan menggunakan tabel dan grafik.

\section{HASIL DAN PEMBAHASAN}

Kefir susu jagung (Zea mays L.Saccharata) diproduksi menggunakan bahan dasar jagung manis. Jagung manis diproduksi terlebih dahulu menjadi susu jagung dengan cara menambahkan air dengan perbandingan 1:6 kemudian campuran tersebut diblender kemudian disaring dan hanya diambil sarinya saja. Kefir susu jagung diproduksi menggunakan 3 komposisi yang berbeda. Komposisi pertama, kefir susu jagung diproduksi dengan bahan baku 100\% sari jagung manis, sedangkan komposisi kedua, kefir susu jagung diproduksi dengan bahan baku $75 \%$ sari jagung manis ditambah $25 \%$ susu skim dan komposisi ketiga, kefir susu jagung diproduksi dengan bahan baku 50\% sari jagung manis ditambah 50\% susu skim.

Sari jagung manis tanpa atau dengan penambahan susu skim kemudian ditambahkan gula pasir sebanyak $8 \%(\mathrm{~b} / \mathrm{v})$ dan dipasteurisasi selama 30 menit pada suhu $85-90^{\circ} \mathrm{C}$. Pemanasan sari susu jagung bertujuan agar gula pasir, sari jagung, dan susu skim dapat bercampur dengan sempurna dan tidak menggumpal. Perebusan susu jagung dalam waktu 30 menit untuk menjaga viskositas susu jagung pasca perebusan. Hal ini sejalan dengan penelitian sebelumnya yang mengkaji tentang karakteristik fisik dan kimia susu jagung manis pada berbagai lama perebusan menunjukkan bahwa lama perebusan susu jagung mempengaruhi viskositas susu jagung secara signifikan. 
Semakin lama waktu perebusan susu jagung, viskositas akan mengalami penurunan. Selain itu, perebusan susu jagung selama 30 menit akan menghasilkan kestabilan emulsi yang lebih baik dibandingkan dengan susu jagung yang direbus selama lebih dari 30 menit. Adapun kadar gula susu jagung yang direbus selama 30 menit lebih tinggi dibandingkan dengan susu jagung yang direbus selama 45 menit dan 75 menit (Muhajir dkk. 2014).

Jagung memiliki kandungan pati yang sangat tinggi (72-73\%) yaitu pati amilosa dan amilopektin dengan perbandingan $25-30 \%: 70-75 \%$. (Suarni dan Widowati, 2015). Jagung juga mengandung karbohidrat oligosakarida dalam bentuk frukto oligo sakarida (FOS) dan gula pereduksi dalam bentuk rafinosa dan stakhiosa (Muchtadi, 2006; Pravitasari, 2009). Adanya kandungan pati (amilosa dan amilopektin) dan fruktooligosakarida serta penambahan gula pasir (sukrosa) sebanyak $8 \%$ b/v akan meningkatkan kadar gula pada susu jagung, sehingga diharapkan dapat menjadi substrat yang baik bagi pertumbuhan mikro organisme dalam kefir grains selama proses fermentasi kefir berlangsung. Hal ini didukung dengan penelitian yang dilakukan oleh Yunus dan Zubaidah (2015) yang mengkaji tentang pengaruh konsentrasi sukrosa dan lama fermentasi terhadap viabilitas L.casei selama penyimpanan beku velva pisang ambon, menyatakan bahwa peningkatan konsentrasi sukrosa memberikan pengaruh terhadap peningkatan total gula pada produk akhir. Adapun penambahhan sukrosa pada slurry velva pisang ambon dihitung sebagai total gula, sehingga total gula akan meningkat seiring dengan peningkatan penambahan sukrosa (Yunus dan Zubaidah, 2015).

Adapun selain penambahan gula, susu jagung yang akan diproduksi menjadi kefir juga ditambahkan susu skim dengan komposisi yang bervariasi, yaitu pada perlakuan K2 (penambahan susu skim sebanyak 25\%) dan perlakuan 3 (penambahan susu skim sebanyak 50\%). Penambahan susu skim bertujuan untuk meningkatkan substrat protein dan karbohidrat, sehingga dapat menunjang pertumbuhan mikro organisme kefir. Hal ini didukung dengan penelitian yang dilakukan oleh Diputra, dkk (2016) yang menyatakan bahwa semakin tinggi penambahan susu skim, maka total bakteri asam laktat yang dihasilkan akan semakin tinggi. Bakteri asam laktat yang terkandung dalam kefir grains dapat memecah karbohidrat menjadi asam laktat, sehingga semakin banyak susu skim yang ditambahkan, maka pertumbuhan bakteri asam laktat akan semakin meningkat dan akan meningkatkan pula jumlah total 
mikroba (Diputra dkk., 2016).

Susu jagung yang telah dipasteurisasi, diangin-anginkan terlebih dahulu sambil diukur suhunya sampai mencapai suhu ruangan $\left(+27-30^{\circ} \mathrm{C}\right)$ kemudian ditambahkan kefir grains sebanyak $7 \% \mathrm{v} / \mathrm{v}$ ke dalam setiap formulasi susu jagung (K1, K2, dan K3). Penambahan kefir grains sebanyak $7 \% \mathrm{v} / \mathrm{v}$ bertujuan untuk meningkatkan jumlah total mikroba kefir dan menurunkan $\mathrm{pH}$ kefir di akhir produk. Hal ini sesuai dengan penelitian Safitri dan Swarastuti (2013) yang mengkaji tentang kualitas kefir berdasarkan konsentrasi kefir grain, menyatakan bahwa semakin besar persentase kefir grains yang ditambahkan, maka total mikroba pada produk akhir kefir akan semakin tinggi. Adapun berdasarkan penelitian, penambahan kefir grains dengan konsentrasi $7,5 \%$ memberikan pengaruh yang nyata terhadap total mikroba pada produk akhir kefir (Safitri dan Swarastuti, 2013).

Proses fermentasi kefir berlangsung selama 24 jam kemudian produk akhir kefir disaring untuk memisahkan kefir dengan kefir grains. Fermentasi selama 24 jam bertujuan untuk meningkatkan kekentalan produk akhir kefir. Semakin tinggi kefir grains yang ditambahkan dan semakin singkat waktu fermentasi, maka semakin kental produk akhir kefir yang dihasilkan. Hal ini sesuai dengan penelitian yang dilakukan oleh Yusriyah dan Agustini (2014) yang mengkaji pengaruh waktu fermentasi dan konsentrasi bibit kefir terhadap mutu kefir susu sapi menunjukkan hasil bahwa produk akhir kefir yang paling kental diperoleh dari proses fermentasi kefir selama 24 jam (Yusriyah dan Agustini, 2014).

Karakteristik Kimiawi (Kadar Karbohidrat, Lemak, dan protein) Kefir Susu Jagung

Kefir susu jagung yang telah diproduksi melalui proses fermentasi selama 24 jam kemudian dianalisis karakteristik kimiawi yang meliputi kadar karbohidrat, kadar lemak, dan kadar protein. Adapun analisis kadar karbohidrat kefir susu jagung dalam penelitian ini menggunakan metode Luff Scrhoorl, yang mana metode ini akan menganalisis kadar total glukosa yang ada pada kefir susu jagung. Analisis kadar lemak kefir susu jagung dalam penelitian ini menggunakan metode Weibull, dan kadar protein susu jagung dianalisis menggunakan metode Kjeldahl. Analisis kadar karbohidrat, protein, dan lemak dilakukan sebanyak tiga (3) kali ulangan. Hasil analisis kandungan zat gizi (kadar karbohidrat, protein, dan lemak) kefir susu jagung pada berbagai formulasi dapat dilihat pada Tabel 2. 
Tabel. 2 Kandungan Zar Gizi Kefir Susu Jagung pada Berbagai Formulasi

\begin{tabular}{|c|c|c|c|}
\hline \multirow{2}{*}{$\begin{array}{l}\text { Kode } \\
\text { Sampel }\end{array}$} & \multicolumn{3}{|c|}{$\begin{array}{c}\text { Kandungan Zat Gizi (\%) } \\
(\text { Rerata }+ \text { SD) }\end{array}$} \\
\hline & $\mathbf{P}$ & Kh & $\mathbf{L}$ \\
\hline K1 & $0.94 \pm 0.006^{\mathrm{a}}$ & $8.58 \pm 0.015^{\mathrm{a}}$ & $0.16 \pm 0.006^{\mathrm{a}}$ \\
\hline K2 & $1.45 \pm 0.050^{\mathrm{b}}$ & $11.86 \pm 0.060^{b}$ & $0.18 \pm 0.003^{b}$ \\
\hline K3 & $3.09 \pm 0.015^{\mathrm{c}}$ & $10.50 \pm 0.006^{\mathrm{c}}$ & $0.20 \pm 0.007^{\mathrm{c}}$ \\
\hline $\begin{array}{l}\text { Uji beda } \\
\text { pada } 0,0 . \\
\text { Notasi } \\
\text { antara pe }\end{array}$ & $\begin{array}{l}\text { rrata menggun } \\
\mathrm{o}=0,0001) \\
\text { uf berbeda } \\
\text { kuan }(a, b, c)\end{array}$ & $\begin{array}{l}\text { kan One Way } \\
\text { ınjukkan perb }\end{array}$ & $\begin{array}{l}\text { ova, signifikar } \\
\text { aan signifikar }\end{array}$ \\
\hline
\end{tabular}

Berdasarkan tabel 2, kadar protein meningkat seiring dengan peningkatan penambahan jumlah susu skim pada susu jagung. Hal ini dikaitkan dengan kandungan susu skim yang tinggi protein, sehingga susu jagung yang ditambahkan susu skim akan mengalami peningkatan kadar protein dibandingkan dengan susu jagung tanpa penambahan susu skim. Hasil penelitian ini sesuai dengan penelitian yang dilakukan oleh Fadro, dkk (2015) yang mengkaji tentang pengaruh penambahan susu skim dalam pembuatan minuman probioik susu jagung (Zea mays L.) menggunakan kultur Lactobacillus acidophilus yang menyatakan bahwa penambahan susu skim akan meningkatkan kadar protein minuman probiotik susu jagung secara signnifikan. Adapun protein yang baik yang berasal dari jagung maupun susu jagung merupakan substrat penting untuk pertumbuhan mikro organisme kefir (kefir grains). Protein merupakan senyawa yang digunakan untuk pembentukan sel-sel mikro organisme kefir (Fadro dkk, 2015). Hasil penelitian ini juga sejalan dengan penelitian yang dilakukan oleh Diputra, dkk (2016) yang mengkaji tentang pengaruh penambahan susu skim terhadap karakteristik yogurt jagung manis (Zea mays L. Saccharata) yang menyatakan bahwa penambahan susu skim dapat meningkatkan kadar protein yogurt secara signifikan. Semakin tinggi susu skim yang ditambahkan pada susu jagung manis, maka kadar protein produk akhir yogurt akan semakin tinggi (Diputra, 2016).

Berdasarkan CODEX Standard for Fermented Milk (CODEX STAN 2342003), kadar protein kefir minimal adalah 2,7\% (FAO, 2010). Mengacu pada standar tersebut, kefir susu jagung dalam penelitian ini yang memenuhi standar minimal kadar protein hanya formulasi K3 (Susu jagung $50 \%$ + susu skim 50\%) dengan kadar protein sebesar 3,09+0,015\% sedangkan formulasi kefir susu jagung K1 dan K2 masih belum memenuhi standar minimal kadar protein, karena hanya mengandung protein kurang dari 2,7\% (berturut-turut sebesar 0,94 + 0,006\% dan 1,45+0,050\%). Adapun kadar protein kefir susu jagung hasil penelitian ini lebih rendah $(0,94+$ $0,006 \% ; 1,45+0,050 \% ;$ dan 3,09+0,015) dibandingkan dengan kadar protein kefir susu kambing. Hal ini sejalan dengan penelitian yang dilakukan oleh 
Setyawardani, dkk (2017) yang menyatakan bahwa kadar protein kefir susu kambing yang dihasilkan berkisar antara $3,30+0,24$ hingga $4,17+0,54 \%$. Kadar protein produk akhir kefir diduga dipengaruhi karena adanya mikro organisme proteolitik dalam kefir grains. Semakin lama waktu fermentasi dalam pembuatan kefir, maka pemecahan atau degradasi protein yang terjadi akan semakin tinggi. Hal ini didukung dengan penelitian yang dilakukan oleh Yusriyah, dkk (2014) yang menyatakan bahwa waktu fermentasi berpengaruh secara signifikan terhadap laju degradasi protein. Adapun degradasi protein yang terjadi selama proses fermentasi dikaitkan dengan adanya mikro organisme proteolitik dalam kefir grains yang dapat mendegradasi atau memecah protein menjadi protein terlarut maupun struktur protein yang lebih sederhana berupa peptida maupun asamasam amino (Yusriyah, 2014).

Mikro organisme yang terkandung dalam kefir grains terdiri dari mikro organisme bakteri Lactobacillus kefiri, Leuconostoc, Lactococcus dan Acetobacter serta mikro organisme yeast Kluyveromyces marxianus (yeast yang mem-fermentasi laktosa) dan Saccharomyces unisporus, Saccharomyces cerevisiae, Saccharomyces exiguous (yeast yang tidak mem-fermentasi laktosa) (FAO, 2010). Proses fermentasi berlangsung secara bertahap, pada 24 jam masa inkubasi, bakteri asam laktat Streptococci tumbuh sangat pesat, sehingga menurunkan tingkat keasaman $(\mathrm{pH})$ produk akhir kefir. Penurunan $\mathrm{pH}$ tersebut akan meningkatkan pertumbuhan bakteri Lactobacilli dan menurunkan pertumbuhan bakteri Streptococci (Farnworth, 2005).

Berdasarkan tabel 2, kadar lemak kefir susu jagung mengalami peningkatan seiring dengan semakin meningkatnya jumlah penambahan susu skim. Hal ini sejalan dengan penelitian yang dilakukan oleh Diputra (2016) yang menyatakan bahwa penambahan susu skim dapat meningkatkan kadar lemak produk akhir yogurt susu jagung manis secara signifikan. Adapun jika dibandingkan dengan standar kadar lemak kefir berdasarkan CODEX, kadar lemak kefir susu jagung sudah memenuhi standar yang ditetapkan yaitu <10\% (FAO, 2010). Rendahnya kadar lemak kefir yang dihasilkan dikaitkan dengan rendahnya kadar lemak jagung manis dan susu skim yang digunakan sebagai bahan baku. Hal ini didukung dengan penelitian yang dilakukan oleh Sawitri (2011) yang menyatakan bahwa susu skim yang digunakan sebagai bahan dasar pembuatan kefir memiliki kadar lemak 1\%, sehingga produk akhir kefir memiliki karakteristik kadar lemak yang rendah (Sawitri, 2011). Kadar lemak yang terkandung dalam 
produk akhir kefir selain dipengaruhi kadar lemak bahan baku juga dikaitkan dengan adanya aktivitas lipolitik yang dihasilkan oleh bakteri asam laktat. Selama proses fermentasi kefir, bakteri asam laktat mengalami pertumbuhan dan menghasilkan enzim lipase. Semakin tinggi pertumbuhan mikroorganisme akan semakin banyak enzim lipase yang dihasilkan, sehingga lemak akan terhidrolisis dalam jumlah yang semakin banyak dan mengakibatkan turunnya kadar lemak pada produk akhir kefir (Sawitri, 1996).

Tabel 2 juga menunjukkan adanya peningkatan kadar karbohidrat kefir susu jagung karena adanya penambahan susu skim, meskipun pada formulasi kefir dengan penambahan $50 \%$ susu skim menghasilkan kadar karbohidrat yang lebih rendah dibandingkan dengan kefir dengan formulasi penambahan $25 \%$ kefir. Peningkatan kadar karbohidrat produk akhir kefir dikaitkan dengan adanya penambahan susu skim. Hal ini dikaitkan dengan adanya laktosa sebagai substrat pertumbuhan mikro organisme kefir (kefir grains). Susu jagung yang difermentasikan menjadi kefir tidak mengandung laktosa, sehingga substrat pertumbuhan mikro organisme hanya berasal dari banyaknya sukrosa yang ditambahkan dalam susu jagung manis. Kadar karbohidrat yang terbentuk pada produk akhir kefir susu jagung tanpa penambahan susu skim merupakan hasil pemecahan substrat sukrosa dari gula pasir serta kandungan pati yang terdapat pada jagung manis. Penelitian yang dilakukan oleh Liu dan Lin (2000) menyatakan bahwa bakteri asam laktat dalam kefir grains tumbuh dan berkembang biak lebih lambat pada substrat susu kedelai dibandingkan dengan susu sapi. Hal ini dikaitkan dengan lambatnya laju pertumbuhan bakteri asam laktat akibat lambatnya produksi faktor pertumbuhan mikro organisme di awal proses fermentasi (Liu dan Lin, 2000).

\section{Daya Simpan Kefir Susu Jagung}

Kefir susu jagung manis yang telah diproduksi kemudian dimasukkan ke dalam wadah tertutup dan disimpan di dalam refrigerator pada suhu berkisar antara $2-8^{0} \mathrm{C}$ selama 35 hari. Adapun karakteristik kefir susu jagung manis yang diamati antara lain: warna, aroma dan tekstur. Pengamatan dilakukan di awal dan di akhir penyimpanan yaitu di hari ke-35.

Karakteristik warna kefir susu jagung sebelum disimpan di refrigerator menunjukkan warna yang berbeda untuk setiap komposisi. Kefir formulasi K1 (tanpa penambahan susu skim) menunjukkan warna kuning yang lebih menyolok dibandingkan dengan kefir fofrmulasi K2 dan K3 yang ditambahkan susu skim. Adapun kefir formulasi K2 dan 
K3 memiliki warna yang hampir sama yaitu kuning pucat (K2) dan krem (K3). Hal ini dikaitkan dengan adanya penambahan susu skim pada formulasi kefir K2 dan K3. Semakin banyak susu skim yang ditambahkan dalam formulasi kefir, semakin pudar warna kuning yang dihasilkan. Penyimpanan selama 35 hari di dalam refrigerator mengakibatkan adanya perubahan terhadap karakteristik warna kefir susu jagung, meskipun warna yang tampak di akhir penyimpanan lebih pudar jika dibandingkan dengan warna kefir susu jagung di awal penyimpanan. Hal ini dikaitkan dengan adanya kerusakan pigmen warna karotenoid yang secara alami terdapat pada jagung manis yang merupakan bahan baku pembuatan kefir. Didukung literatur yang menyebutkan bahwa jagung memiliki beberapa pigmen antara lain: antosianin (antosianidin, aglikon, glukosida), karotenoid dan lainnya (Suarni dan Yasin, 2011).

Karakteristik tekstur kefir susu jagung sebelum disimpan di refrigerator berbeda untuk setiap komposisi kefir. Kefir formulasi K1 (tanpa penambahan susu skim) menunjukkan tekstur cair dan terdapat granula putih kecil. Adapun kefir formulasi K2 menunjukkan tekstur kefir yang sedikit lebih kental dibandingkan dengan kefir formulasi K1. Formulasi K2 juga terdapat granula putih kecil yang lebih banyak dibandingkan dengan kefir formulasi K1. Hal ini yang membuat tekstur formulasi kefir K2 lebih kental dan lebih kasar dibandingkan formulasi $\mathrm{K} 1$. Kefir formulasi K3 menunjukkan tekstur yang sangat berbeda jika dibandingkan dengan kefir formulasi K1 dan K2. Granula putih yang terbentuk lebih banyak dan tampak membentuk gumpalan, sehingga tekstur kefir formulasi K3 lebih kental dan paling kental jika dibandingkan dengan kefir formulasi K1 dan K2. Kekentalan tekstur kefir susu jagung dikaitkan dengan adanya penambahan susu skim dalam proses pembuatan kefir susu jagung. Penambahan susu skim dalam formulasi kefir susu jagung akan mempengaruhi total padatan kefir susu jagung. Semakin tinggi total padatan kefir susu jagung, semakin kental tekstur produk susu kefir yang dihasilkan. Hal ini sesuai dengan hasil penelitian yang dilakukan oleh Fadro dkk (2015) tentang pengaruh penambahan susu skim dalam pembuatan minuman probiotik susu jagung menggunakan kultur Lactobacillus acidophilus yang menyatakan bahwa penambahan susu skim meningkatkan total padatan minuman probiotik susu jagung secara signifikan. Semakin tinggi total padatan, akan semakin kental tekstur produk yang dihasilkan (Fadro dkk, 2015). Perubahan karakteristik warna dan tekstur kefir susu jagung pada berbagai formulasi kefir dapat dilihat pada Gambar 2. 
Selain warna dan tekstur, karakteristik yang diamati selama penyimpanan kefir susu jagung adalah aroma. Adapun sebelum disimpan dalam refrigerator, aroma kefir yang terbentuk cenderung asam seperti produk fermentasi susu pada umumnya. Aroma khas susu fermentasi semakin muncul dengan semakin banyak jumlah susu skim yang ditambahkan dalam susu jagung manis.

Aroma khas kefir akan semakin meningkat seiring lamanya waktu penyimpanan kefir dalam refrigerator. Hal ini dikaitkan dengan proses fermentasi dan pembentukan senyawa aroma kefir yang masih tetap dihasilkan selama masa penyimpanan. Penelitian yang dilakukan oleh Cais-Sokolińska et al (2008) tentang karakteristik fisikokimia dan sensori kefir susu kambing yang disimpan pada suhu $6+1^{0} \mathrm{C}$ selama 21 hari menunjukkan hasil bahwa selama penyimpanan akan terbentuk aroma asam dan aroma khas kefir yang kadarnya akan semakin meningkat seiring dengan lamanya waktu penyimpanan. Starter kefir yang terdiri dari bakteri asam laktat dan yeast akan menghasilkan karbon dioksida selama proses pembentukan asam laktat. Selain itu starter kefir juga akan menghasilkan etanol, asetaldehid, diasetil dan asam aseton yang akan menghasilkan flavor dan aroma kefir yang khas (Beshkova et al, 2003).

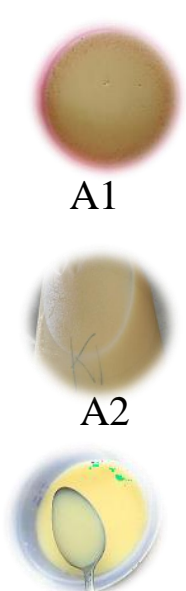

a1

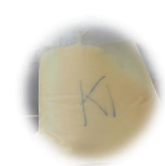

a2

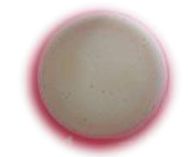

B1

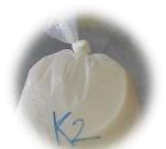

B2

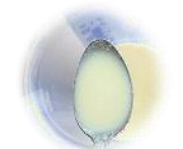

b1

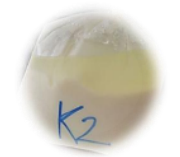

b2

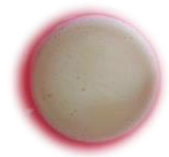

C1

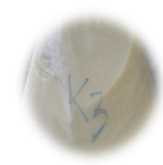

$\mathrm{C} 2$

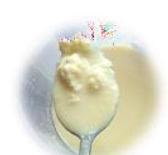

c1

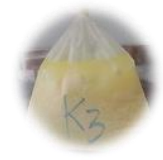

c2

Gambar 1. Karakteristik Warna dan Tekstur Kefir Susu Jagung

A1, B1, dan C1 adalah kenampakan warna kefir susu jagung sebelum penyimpanan.

A2, B2, dan C2 adalah kenampakan warna kefir susu jagung setelah 35 hari penyimpanan suhu refrigerator.

a1,b1, dan c1 adalah kenampakan tekstur kefir susu jagung sebelum penyimpanan. a2,b2, dan c2 adalah kenampakan tekstur kefir susu jagung setelah 35 hari penyimpanan suhu refrigerator.

A,a $=$ kefir susu jagung tanpa penambahan susu skim

$\mathrm{B}, \mathrm{b}=$ kefir susu jagung yang ditambahkan $25 \%$ susu skim $\mathrm{C}, \mathrm{c}=$ kefir susu jagung 
yang ditambahkan 50\% susu skim.

\section{KESIMPULAN DAN SARAN}

\section{Kesimpulan}

1. Terjadi peningkatan kadar karbohidrat, protein, dan lemak kefir susu jagung seiring dengan peningkatan penambahan jumlah susu skim.

2. Terjadi perubahan karakteristik warna kefir susu jagung menjadi lebih pudar, tekstur yang lebih menggumpal dan aroma yang lebih masam dalam waktu 35 hari penyimpanan kefir susu jagung pada suhu refrigator.

\section{Saran}

1. Perlu adanya penelitian lebih lanjut yang mengkaji tentang karakteristik mikrobiologis kefir susu jagung dan uji kesukaan panelis terhadap kefir susu jagung yang diproduksi untuk melengkapi hasil penelitian sebelumnya.

2. Perlu adanya pemanfaatan bahan bahan nabati lainnya yang memiliki karakteristik kandungan gizi yang baik sebagai pangan fungsional dengan memanfaatkan teknologi fermentasi.

\section{DAFTAR PUSTAKA}

Andrade E.F., Lima A.R.V., Nunes I.E., Orlando D.R., Godim P.N.,
Zangeronimo M.G., et al. 2016. Exercise and Beta-Glucan Consumption (Saccharomyces cerevisiae) Improve the Metabolic Profile and Reduce the Atherogenic Index in Type 2 Diabetic Rats (HFD/STZ). Nutrients, Vol 8. 792

Balai Besar Penelitian dan Pengembangan Pascapanen Pertanian. 2007. Kefir, Susu Fermentasi dengan Rasa Menyegarkan. Warta Penelitian dan Pengembangan Pertanian, Vol 29(2), 12-14.

Beshkova, D., E. Simova, G. Frengova, Z. Simov, and Z. P. Dimitrov. 2003. Production of volatile aroma compounds by kefir starter cultures. Int. Dairy J, Vol 13. 529-535.

Cais-Sokolińska, D., Danków, R. and Pikul, J. 2008. Physicochemical and sensory characteristics of sheep kefir during storage. Acta Science Polland Technology Alimenttarius, 7(2). 6373.

Diputra, K. W., Puspawati N. N., Hapsari, A. N. I. 2016. Pengaruh Penambahan Susu Skim terhadap Karakteristik Yogurt Jagung Manis (Zea Mays L. Saccharata). Jurnal Ilmu dan Teknologi Pangan, Vol 5(2). 142-52.

Fadro, Efendi R; dan Restuhadi F. 2015. Pengaruh Penambahan Susu Skim dalam Pembuatan Minuman Probiotik Susu Jagung (Zea mays L.) Menggunakan Kultur Lactobacillus acidophilus. SAGU, Vol 14(2). 2836.

Farnworth, E. R. Kefir - A Complex Probiotic. 2005. Food Science and Technology Bulletin: Functional Foods, Vol 2(1). 1-17

Liu, J.R., dan Lin, C.W. 2000. Production of Kefir from Soymilk with or without Added Glucose, Lactose or Sucrose. Journal of Food Science, Vol 65. 716-719.

Muchtadi, D. 2006. Karbohidrat dalam 
Makanan Bayi. Food review Referensi Industri dan Teknologi Pangan Indonesia, Vol 1(3). 44-5.

Muhajir, R., Raim A., dan Hutomo, G.S. 2014. Karakteristik Fisik dan Kimia Susu Jagung pada Berbagai Lama Perebusan. J.Agroland, Vol 21(2). 95-103.

Nurliyani, Harmayani, E., and Sunarti. 2015. Antidiabetic Potential of Kefir Combination from Goat Milk and Soy Milk in Rats Induced with Streptozotocin-Nicotinamide.

Korean J. Food Science, Vol. 35(6). 847-58.

Nurliyani, N., Harmayani, E., \& Sunarti, S. 2014. Manfaat Kefir Susu Kambing dan Susu Kedelai dalam Perbaikan Profil Lipid Tikus yang Diinduksi Diabetes type 2. Skripsi. Yogyakarta: UGM

Pravitasari, R. 2009. Pengaruh Perendaman dalam Larutan Gula terhadap Persentase Oligosakarida dan Sifat Sensorik Tepung Kacang Kedelai (Glycine Max). Skripsi. Surakarta: Universitas Muhammadiyah Surakarta.

Purnomo H \& Muslimin L.D. 2012. Chemical Characteristics off Pasteurised Goat Milk and Goat Milk Kefir Prepared using Different Amount of Indonesian Kefir Grains and Incubation Times. International Food Research Journal, Vol 19(2). 791-94.
Safitri M.F dan Swarastuti. 2013 Kualitas Kefir Berdasarkan Konsentrasi Kefir Grain. Jurnal Aplikasi Teknologi Pangan, Vol 2(2). 87-92.

Sawitri, M.E. 1996. Pengaruh Konsentrasi Kefir Grains terhadap Kualitas Kefir. Malang: Laporan Penelitian Fakultas Peternakan, Universitas Brawijaya.

Sawitri, M.E. 2011. Kajian Konsentrasi Kefir Grain dan Lama Simpan dalam Refrigerator teradap Kualitas Kimiawi Kefir Rendah Lemak. JIIPB, Vol 21. 23-28.

Suarni \& Widowati, S. Struktur, 2015. Komposisi, dan Nutrisi Jagung. Bogor: Balai Besar Penelitian dan Pengembangan Pasca Panen Pertanian.

Suarni dan Yasin M. 2011. Jagung sebagai Sumber Pangan Fungsional. Iptek Tanaman Pangan, Vol 6(1). 41-56.

Yunus, Y., dan Zubaidah, E. 2015. Pengaruh Konsentrasi Sukrosa dan Lama Fermentasi terhadap Viabilitas L.Casei selama Penyimpanan Beku Velva Pisang Ambon. Jurnal Pangan dan Agroindustri, Vol 3(2). 303-12.

Yusriyah, N. H \& Agustini R. 2014. Pengaruh Waktu Fermentasi dna Konsentrasi Bibit Kefir Terhadap Mutu Kefir Susu Sapi. Journal of Chemistry, Vol 3(2). 53-7. 